\title{
Improving Employee Performance Through Implementing Transformational Leadership Style, Organizational Culture Improvement and Work Motivation
}

\author{
Ade Riandi Virgiawan ${ }^{1}$, Setyo Riyanto ${ }^{2}$ \\ Magister of Management Mercu Buana University, Jakarta, Indonesia \\ Associate Professor Mercu Buana University, Jakarta, Indonesia
}

\begin{abstract}
This study aims to examine and analyze the effect of Transformational Leadership Style, Organizational Culture, and Motivation on Employee Performance in the Human Resources Development Agency. This type of research is quantitative, with a total population of 468 employees, the determination of the number of samples do use the Slovin formula with the results of the sample calculation of 99.78 or 100 people. The results of this study indicate that the Transformational Leadership Style dimension does not significantly influence Employee Performance, Organizational Culture, and Motivation has a positive and significant influence. The Transformational Leadership Style, Organizational Culture, and Motivation simultaneously have positive and significant impacts on Employee Performance. Based on these results, it can suggest that the organization can recommend and compile transformational leadership training modules both at the official and staff level. Besides, it is necessary to increase the capacity of employees in each Work Unit in the form of FGDs related to transformational leadership. This study is limited to one Human Resources Development Agency. For further studies, it would be better if this research conduct for several Organizational Units in a Ministry / Institution.
\end{abstract}

Keywords:- Employee Performance, Transformational Leadership Style, Organizational Culture and Motivation.

\section{INTRODUCTION}

Infrastructure is critical in realizing the fulfillment of people's fundamentals, such as food, clothing, housing, security, education, and health. Infrastructure also plays an essential role in supporting national economic growth and global competitiveness. As a ministry that deals with infrastructure, it is obliged to support this through the implementation of integrated, effective, and efficient development by taking into account the mainstreaming of sustainable development, gender, and based on good governance in the process of achieving national development goals.

At this time, Indonesia is building various types of infrastructure on a large and wide-scale to prepare the foundation for the welfare of the population in the future, so it is in urgent need of competent Human Resources (HR) and an adequate amount.

Improving human resource competency is the task of the Human Resources Development Agency (BPSDM). BPSDM has HR development targets in the form of programs and activities that have set as indicators of the success of its performance over one year. Apart from programs and activities, financial planning is an essential factor that must be determined because today's budget is included in performance measurement tools or termed performance-based budgeting.

Based on e-Monitoring data on budget implementation, financial targets have not been able to be achieved $100 \%$ over the past three years, as shown in table 1: 
ISSN No:-2456-2165

\begin{tabular}{|c|c|c|c|}
\hline ORGANIZATION UNIT & \multirow{2}{*}{ FISCAL YEAR } & FINANCIAL TARGETS & FINANCIAL REALIZATION \\
\cline { 3 - 4 } & & $\mathbf{( \% )}$ & $\mathbf{( \% )}$ \\
\hline BPSDM & 2018 & 100 & 93.38 \\
\hline DEPJEN BK & 2018 & 100 & 98.94 \\
\hline DEPJEN PnP & 2018 & 100 & 95.10 \\
\hline ORGANIZATION UNIT & FISCAL YEAR & FINANCIAL TARGETS & FINANCIAL REALIZATION \\
\cline { 3 - 4 } & & $\mathbf{( \% )}$ & $\mathbf{( \% )}$ \\
\hline BPSDM & 2017 & 100 & 97.98 \\
\hline DEPJEN BK & 2017 & 100 & 92.01 \\
\hline DG BM & 2017 & 100 & 94.34 \\
\hline DEPJEN PnP & 2017 & 100 & $\mathbf{( \% )}$ \\
\hline ORGANIZATION UNIT & FISCAL YEAR & FINANCIAL TARGETS & FINANCIAL REALIZATION \\
\cline { 3 - 4 } & & $\mathbf{( \% )}$ & 89.48 \\
\hline BPSDM & 2016 & 100 & 91.69 \\
\hline SETJEN & 2016 & 100 & 91.50 \\
\hline BALITBANG & 2016 & 100 & \\
\hline & & &
\end{tabular}

Table 1:- BPSDM Budget Implementation Report

Source: e-Monitoring (T.A 2016-2018)

In 2016 BPSDM's financial realization was 89.48\%; this value is still below the commercial recognition at the Secretariat General (SETJEN) and the Research and Development Agency (BALITBANG). In 2017 the financial realization of BPSDM was $87.98 \%$. However, the value was still below the Organizational Unit of the Directorate General of Construction (95.01\%), the Directorate General of Highways $(92.49 \%)$, and the Directorate General of Housing Provision (94.34\%). In 2018, the financial realization of BPSDM was quite high (93.38\%), but the figure is still below DG BK $(98.94 \%)$ and DGN PNP (95.10\%).

The data above shows the existence of GAP performance that affects the absorption of the budget of the Organization Unit of the Human Resources Development Agency. This gap also indicates that the performance of BPSDM has not been optimal and fluctuated over the past three years.

In addition to these data, researchers tried to obtain information about the possibility of a decline in organizational performance by providing questionnaires as a form of assessment of the Employee Performance as implementing activities.

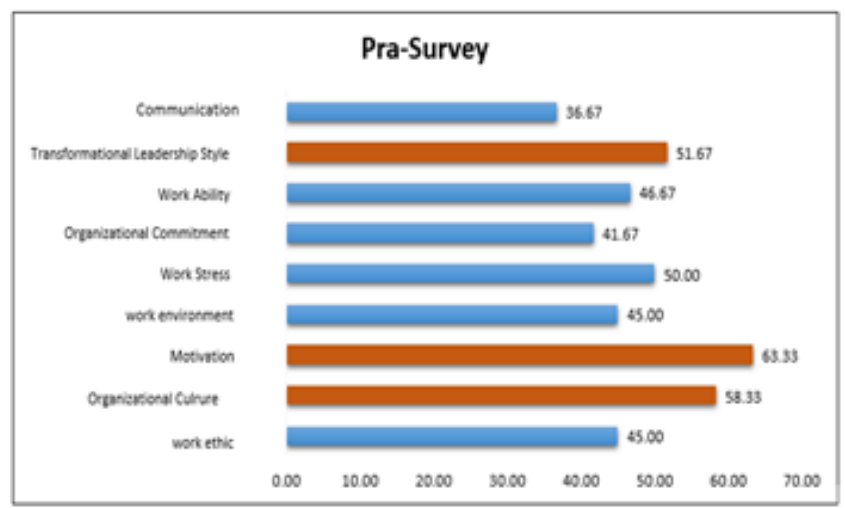

Fig. 1:- Pre-Survey Data

Source: Primary Data pre-research, 2019
The pre-survey data shows that the three highest variables influence organizational performance that is not optimal, namely the Transformational Leadership Style, Organizational Culture, and Motivation variables.

Based on the data above, researchers are interested in researching the title "Improving Employee Performance Through the Implementation of Transformational Leadership Style, Improving Organizational Culture and Motivation."

\section{THEORETICAL REVIEW}

\section{A. The Performance}

The achievement of organizational goals cannot separate from the resources owned by the organization run by employees who play an active role as actors in efforts to achieve the purposes of the organization. According to Sinambela (2012: 181), organizational performance is cumulative Employee Performance; therefore, the higher the Employee Performance, the higher the organizational performance.

Dimensions or performance indicators are aspects that become a measure in evaluating performance. Sizes and signs are used as benchmarks in assessing performance and will be very necessary because it is beneficial for many parties. According to John Miner in Sudarmanto (2015), Dimensions and performance indicators are:

\section{Quality:}

Quality is a standard that must be achieved by a person, group, or organizational institution regarding the condition of human resources, the variety of work methods, as well as the goods and services produced. Quality indicators, according to Jhon Miner, namely:

- Error rate,

- The level of damage,

- The degree of accuracy. 


\section{Quantity:}

An organization already has goals to be achieved. To measure the performance of the apparatus in achieving these objectives can undoubtedly be seen from the amount of work that has produce or effectiveness.

\section{$>$ Working time:}

Effective use of time will produce an excellent performance for the apparatus and can realize the goals of an organization. If the equipment effectively uses work time, it will create the effectiveness of organizational performance. According to John Miner that there are three indicators contained in the measurement of time using that can be seen, namely:

- Level of absence

- The level of delay

- Use of work time

$\checkmark$ Collaboration with others in working:

Cooperation is one of the factors found in an organizational environment. To create a strong team to help achieve the goals of an organization, the team needs that can work together with each other.

\section{B. Transformational Leadership}

According to Yulk (2015: 315), Transformational Leadership Style can see from followers who feel the trust, admiration, loyalty, and respect for leaders, and they are motivated to do more than they initially expected.

Leaders change by motivating followers by making more aware of the importance of the results of the task, persuading them to put their team or organization's interests first rather than personal interests.

(Bass and Avolio in Ahmad et al., 2014) identified four dimensions of transformational leadership:

- Idealized Influence: Leaders who behave as role models, are admired, respected, and trusted. The leader is willing to take risks, be reliable, and have good moral and ethical behavior.

- Inspirational Motivation: Leaders who show enthusiasm, optimism, and create a work atmosphere that is committed to achieving the goals and vision of the organization, and leaders who can communicate high expectations, focus on efforts and express essential goals.

- Intellectual Stimulation: Leaders who encourage the creativity of followers and encourage breakthroughs in solving problems.

- Individualized Consideration: Leaders who pay attention to the needs of each individual for achievement and growth by acting as a coach or mentor.

\section{Organizational Culture}

Robbins, Stephen P, Judge, (2009), states that Organizational Culture is a system of shared meanings shared by members that distinguish the organization from other organizations.
According to Robbins \& Coulter (2012: 52), there are seven dimensions of Organizational Culture, namely:

- Innovation and the courage to take risks (Innovation and risk-taking), is the extent to which the organization encourages employees to be innovative and dare to take risks. Besides, how organizations appreciate the risktaking actions by employees and generate employee ideas.

- Attention to detail is the extent to which organizations expect employees to show accuracy, analysis, and attention to features.

- Results-oriented is the extent to which management focuses on outcomes rather than care to the techniques and processes used to achieve this.

- People-oriented is the extent to which management decisions take into account the effects of results on people in the organization.

- Team oriented, is the extent to which work activities organizes around teams, not individual individuals.

- Aggression is the extent to which people in the organization are aggressive and competitive to run Organizational Culture as well as possible.

- Stability is the extent to which organizational activities emphasize the status quo (maintaining what is because it is considered good enough) rather than growth.

\section{Motivation}

According to Robbins in Mamik (2010) that work motivation is an encouragement that makes a person act or behaves with the possibility of meeting personal goals or needs at work.

According to Mc. Cleland (Robbins and Judge, 2014: 207), Motivation dimensions and indicators namely:

- Need for achievement (need for performance)

The need for success is a need and encouragement to do something new at work, motivation to be able to do work better than before, and always wants to achieve higher achievements. An employee who requires high achievers will tend to take risks.

\section{- Need for affiliation (need for membership)}

The requirement for membership is an encouragement to be able to interact with others, be with other people, work together in teams, do not want to do something that harms others.

\section{- $\quad$ The need for power (need for energy)}

The need for control is a need for encouragement to have the ability. Which is a reflection of the drive to achieve authority to have an influence on others, and be at the forefront of many things.

\section{E. Framework}

Based on previous theoretical studies and research on the influence of independent variables (Transformational Leadership Style, Organizational Culture, and Motivation) on the dependent variable (Employee Performance). The data obtained by researchers in the background of the study, it is assumed that each of the independent variables 
ISSN No:-2456-2165

has an influence positive towards Employee Performance in the Human Resources Development Agency. The researcher develops the following framework:

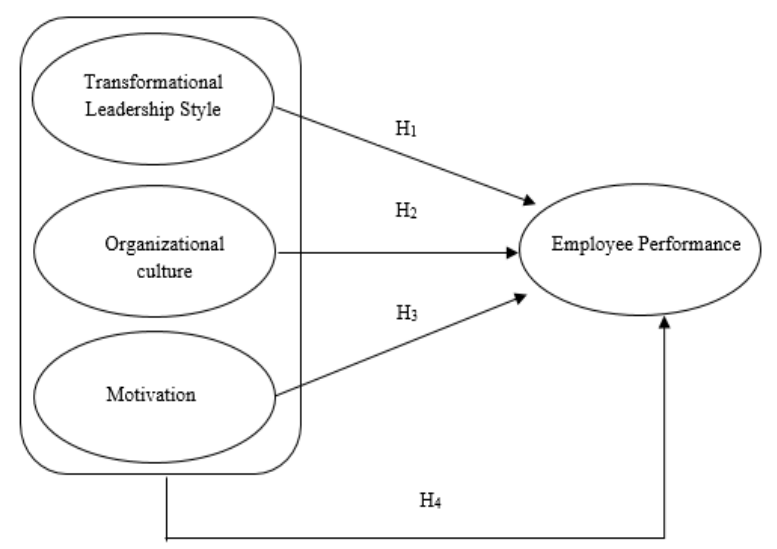

Fig 2:- Conceptual Framework

Source: Data processed by researchers, 2019

\section{F. Hypothesis}

$\mathrm{H}_{1}$ : Transformational leadership influences Employee Performance;

$\mathrm{H}_{2}$ : Organizational Culture influences Employee Performance;

$\mathrm{H}_{3}$ : Work motivation affects EmployeePerformance;

$\mathrm{H}_{4}$ : Transformational Leadership Style, organizational culture, and motivation simultaneously have a positive and significant effect on employees performance

\section{METHODOLOGY}

In this study, researchers aimed to test the hypothesis the research design used was a Causal Study. Causal research use to prove the relationship between the cause and effect of several variables. Causal research usually uses the experimental method by controlling the independent variables that will affect the dependent variable in the situation that has a plan. This study examines the influence of Transformational Leadership Style, Organizational Culture, and Motivation on Employee Performance.

The population in this study is civil servants in the Organizational Unit of the Human Resources Development Agency who have not yet entered the retirement preparation period (MPP). Based on staffing data (e-HRM), the number of BPSDM employees in 2019 is as many as 468 people and are active or not yet retired civil servants (MPP).

The sampling method in this study uses the Slovin formula with an error rate of $10 \%$ because, in sampling, the number must be representative so that research results can be generalized. From the calculation of the Slovin formula, a sample of 99.78 produces or rounded up to 100 people.

The quality test of the research instrument (questionnaire) carried out the reliability test, the validity test, and the classic assumption test, which consisted of a normality test, a multicollinearity test, and a heteroskedasticity test.

For data analysis in proving hypotheses, multiple linear regression analysis uses, the coefficient of determination test (r2) to measure how far the model's ability to explain the variation of the dependent variable, partial test (t-test) to find out how far the influence of the independent variable $(\mathrm{X})$, on the dependent variable $(\mathrm{Y})$ partially. The simultaneous test ( $\mathrm{F}$ test) to show whether all separate or independent variables included in the model have a joint influence on the dependent variable, and the correlation test between dimensions to measure the level of the relationship involving more than one independent variable (X1, X2, X3), and one dependent variable (Y). Multiple Regression Analysis using SPSS version 23.

\section{RESULT AND DISCUSSION}

\section{A. Reliability Test}

A measurement instrument is said to be reliable if the measurement is consistent and accurate. So the instrument reliability test is carried out in order to find out the consistency of the instrument as a measuring instrument, so that the results of a measurement can be trusted. The formula used to test the reliability of the instrument in this study is the Alpha coefficient $(\alpha)$ from Cronbach. Referring to Ghozali (2011: 48), the evaluation of a construct or variable is said to be reliable if Cronbach Alpha> 0.70.

\begin{tabular}{|c|c|c|c|}
\hline Variable & $\begin{array}{c}\text { Cronbach } \\
\text { s Alpha }\end{array}$ & $\begin{array}{c}\text { Reliability Limi } \\
\text { ts }\end{array}$ & $\begin{array}{c}\text { Reliabilit } \\
\mathrm{y}\end{array}$ \\
\hline $\begin{array}{c}\text { Transformation } \\
\text { al Leadership } \\
\text { Style }\end{array}$ & 0.934 & 0.70 & Reliable \\
\hline $\begin{array}{c}\text { Organizational } \\
\text { culture }\end{array}$ & 0.771 & 0.70 & Reliable \\
\hline Motivation & 0.801 & 0.70 & Reliable \\
\hline $\begin{array}{c}\text { Employee } \\
\text { Performance. }\end{array}$ & 0.762 & 0.70 & Reliable \\
\hline
\end{tabular}

Table 2:- Reliability Test Results

Source: Data processed by researchers, 2019

Table 2 shows that all variables in this study have a Cronbach alpha value greater than 0.70 . So it can be concluded that all the research variables are reliable and suitable to be used as research instruments.

\section{B. Validity Test}

Validity test for each item of questions do by comparing the value of $r$ arithmetic with $r$ table, for the degree of freedom the researcher uses df $=\mathrm{N}-2$, in this study the number of samples used is 100 respondents, then to get the value of $\mathrm{r}$ table is $\mathrm{df}=100-2=98$. The amount of $r$ table is 0.1966 , with a confidence level of $95 \%$. The costs for the decisions that can take are as follows:

- If $r$ count $>r$ table and is positive, then the item is declared valid.

- If $\mathrm{r}$ arithmetic < $\mathrm{r}$ table and is negative, then the question is declared invalid. 
ISSN No:-2456-2165

\begin{tabular}{|c|c|c|c|}
\hline Variable & r Count & r Table & Description \\
\hline $\mathrm{X}_{1.1}$ & 0.823 & 0.1966 & Valid \\
\hline $\mathrm{X}_{1.2}$ & 0.801 & 0.1966 & Valid \\
\hline $\mathrm{X}_{1.3}$ & 0.743 & 0.1966 & Valid \\
\hline $\mathrm{X}_{1.4}$ & 0.744 & 0.1966 & Valid \\
\hline $\mathrm{X}_{1.5}$ & 0,700 & 0.1966 & Valid \\
\hline $\mathrm{X}_{1.6}$ & 0.727 & 0.1966 & Valid \\
\hline $\mathrm{X}_{1.7}$ & 0.703 & 0.1966 & Valid \\
\hline $\mathrm{X}_{1.8}$ & 0,800 & 0.1966 & Valid \\
\hline $\mathrm{X}_{1.9}$ & 0.772 & 0.1966 & Valid \\
\hline
\end{tabular}

Table 3:- Test Results of Transformational Leadership Validity

Source: Data processed by researchers, 2019

\begin{tabular}{|c|c|c|c|}
\hline Variable & r Count & r Table & Description \\
\hline $\mathrm{X}_{2.1}$ & 0.453 & 0.1966 & Valid \\
\hline $\mathrm{X}_{2.2}$ & 0.202 & 0.1966 & Valid \\
\hline $\mathrm{X}_{2.3}$ & 0.569 & 0.1966 & Valid \\
\hline $\mathrm{X}_{2.4}$ & 0.470 & 0.1966 & Valid \\
\hline $\mathrm{X}_{2.5}$ & 0.626 & 0.1966 & Valid \\
\hline $\mathrm{X}_{2.6}$ & 0.416 & 0.1966 & Valid \\
\hline $\mathrm{X}_{2.7}$ & 0.472 & 0.1966 & Valid \\
\hline $\mathrm{X}_{2.8}$ & 0.495 & 0.1966 & Valid \\
\hline $\mathrm{X}_{2.9}$ & 0.552 & 0.1966 & Valid \\
\hline
\end{tabular}

Table 4:-Test Results of Organizational Cultural Validity Source: Data processed by researchers, 2019

\begin{tabular}{|c|c|c|c|}
\hline Variable & r Count & r Table & Description \\
\hline $\mathrm{X}_{3.1}$ & 0.597 & 0.1966 & Valid \\
\hline $\mathrm{X}_{3.2}$ & 0.577 & 0.1966 & Valid \\
\hline $\mathrm{X}_{3.3}$ & 0.487 & 0.1966 & Valid \\
\hline $\mathrm{X}_{3.4}$ & 0.395 & 0.1966 & Valid \\
\hline $\mathrm{X}_{3.5}$ & 0.348 & 0.1966 & Valid \\
\hline $\mathrm{X}_{3.6}$ & 0.292 & 0.1966 & Valid \\
\hline $\mathrm{X}_{3.7}$ & 0.608 & 0.1966 & Valid \\
\hline $\mathrm{X}_{3.8}$ & 0.730 & 0.1966 & Valid \\
\hline $\mathrm{X}_{3.9}$ & 0.413 & 0.1966 & Valid \\
\hline
\end{tabular}

Table 5:- Motivation Validity Test Results

Source: Data processed by researchers, 2019

\begin{tabular}{|c|c|c|c|}
\hline Variable & r Count & r Table & Description \\
\hline $\mathrm{Y}_{1.1}$ & .482 & 0.1966 & Valid \\
\hline $\mathrm{Y}_{1.2}$ & 0.558 & 0.1966 & Valid \\
\hline $\mathrm{Y}_{1.3}$ & 0.436 & 0.1966 & Valid \\
\hline $\mathrm{Y}_{1.4}$ & .383 & 0.1966 & Valid \\
\hline $\mathrm{Y}_{1.5}$ & 0.225 & 0.1966 & Valid \\
\hline $\mathrm{Y}_{1.6}$ & .300 & 0.1966 & Valid \\
\hline $\mathrm{Y}_{1.7}$ & 0.549 & 0.1966 & Valid \\
\hline $\mathrm{Y}_{1.8}$ & 0.531 & 0.1966 & Valid \\
\hline $\mathrm{Y}_{1.9}$ & 0.575 & 0.1966 & Valid \\
\hline
\end{tabular}

Table 6:- Test Results of Validity of Performance

Source: Data processed by researchers, 2019

All values calculated for each statement in this study have benefits above 0.1966 . It shows that every account in this questionnaire is valid.

\section{Data Analysis}

Following are the results of multiple Linear Regression analysis:

\begin{tabular}{|c|c|c|c|c|c|c|}
\hline \multicolumn{2}{|r|}{ Model } & \multicolumn{2}{|c|}{ Unstandardized Coefficients } & \multirow{2}{*}{$\begin{array}{c}\text { Standardized Coefficients } \\
\text { Beta }\end{array}$} & \multirow[t]{2}{*}{$\mathrm{t}$} & \multirow[t]{2}{*}{ Sig. } \\
\hline & & B & Std. Error & & & \\
\hline \multirow[t]{4}{*}{1} & (Constant) & 1,199 & ,424 & & 2,829 & ,006 \\
\hline & $\begin{array}{c}\text { Transformational Leadership } \\
\text { Style }\end{array}$ & ,054 & ,063 & ,088 & ,859 & ,392 \\
\hline & Organizational culture & ,321 & ,122 & ,286 & 2,629 & ,010 \\
\hline & Motivation & , 195 & ,085 & ,231 & 2,283 &, 025 \\
\hline
\end{tabular}

Table 7:- Results of Multiple Linear Regression Tests

Source: Data processed by researchers, 2019

Based on the results of the Multiple Linear Regression above, it can explain that:

- The regression coefficient value of the Transformational Leadership Style is 0.054 . It means that any increase in the value of the Transformational Leadership Style will cause an increase in Employee Performance of 0.054, which positively relate between the Transformational Leadership Style and Employee Performance.

- Organizational culture regression coefficient value of 0.321 . It means that any increase in the amount of
Organizational culture will cause an increase in Employee Performance by 0.321 , which positively relate between Organizational culture and Employee Performance.

- Motivation regression coefficient value of 0.195 . It means that any increase in the cost of Motivation will cause an increase in Employee Performance of 0.195, which positively relate between Motivation and Employee Performance. 
ISSN No:-2456-2165

\section{Correlation Test Between Dimensions}

Based on the Results of Correlation Matrix Tests, it can be seen that:

- Dimensions Aggressive attitude has the most definite relationship with the aspect of Quality of output that is equal to 0.538 . While the size that has the lowest relationship is the Intellectual Simulation dimension to the Time at work dimension that is equal to 0.113 .

- The most stable relationship in the Transformational Leadership Style variable on Employee Performance is the Intellectual Simulation dimension to the Quantity of output dimension that is equal to 0,400 . While the lowest relationship is in the aspects of Intellectual Simulation to Time at work that is equal to 0.113 .

- The most substantial involvement in the Organizational Culture variable on Employee Performance is the dimension of Aggressive Attitudes towards the Quality of output dimension that is equal to 0.538. While the lowest relationship is in the Orientation dimension to the results of the Quantity of output that is equal to 0.115 .

- The most robust involvement in the Motivation variable on Employee Performance is in the Need for Power dimension to the Quality of output dimension that is equal to 0.451 . While the lowest relationship is in the Need for Power dimension to the Quantity of output that is equal to 0.171 .

\section{CONCLUSIONS}

The Transformational Leadership Style variable shows that there is no significant effect on Employee Performance. This assumes that the direct supervisor of employees has not fully implemented the core competencies of the Transformational Leadership Style as an effort to improve management in improving human resources to improve organizational performance.

$>$ Organizational culture has a significant effect on employee performance. This means that employees already understand the work system in the organization's environment so that the organization only needs to oversee the achievement of the organization's performance.

$>$ Motivation at work provides a significant influence on employee performance. These results indicate that employees have a desire to work better and have competitiveness to get a career that has been arranged in a career path.

$>$ Together (simultaneously) the Transformational Leadership Style, Organizational Culture and Motivation variables have a significant effect on Employee Performance. This shows that performance is influenced by the character of leaders who provide better performance by paying attention to the participation of their employees. on the other hand, organizational culture provides a compliant impact and commitment to achieving targets that must be achieved and work systems that must be understood. In addition, the desire and competitiveness of employees has a positive impact on improving organizational performance

\section{REFERENCES}

[1]. Ahmad et all. (2014). Impact of Transformational Leadership on Employee Motivation in Telecommunication Sector, Vol. 2, No. 2, pp. 11-25. Retrieved from American Research Institute for Policy Development.

[2]. Aima, H.,Adam, R. \& Ali, H. (2017). Model of Employee Performance: Competence Analysis and Motivation (Case Study at PT. Bank Bukopin,Tbk Center). Journal of Research in Business and Management, Volume 4 Issue 11 (2017) pp: 49-59. ISSN(Online) : 2347-3002.

[3]. Ghozali, Imam.,2013. Aplikasi Analisis Multivariate dengan Program SPSS.

[4]. Ghozali, Imam. (2011). Aplikasi Analisis Multivariate Dengan Program SPSS. Semarang: Badan Penerbit Universitas Diponegoro.

[5]. Mangkunegara, Anwar Prabu. (2011) Manajemen Sumber Daya Manusia Perusahaan. Edisi Kesepuluh. Bandung: PT. Remaja Rosda Karya.

[6]. Puspitasari,S.O., \& Setyo Riyanto. (2020). The Influences of Transformational Leadership and Training on Succession Management as Mediation Variables in Effort to Increase an Organizational Capability at PT Gama Plantation. International Journal of Innovative Science and Research Technology, Vol 5, Issue 1, pp 1119-1128. ISSN No:2456-2165.

[7]. Robbins, Stephen P, Judge, (2009), Perilaku Organisasi, Orgnizational Behavior, Penerbit Salemba Empat, Jakarta.

[8]. Robbins, Stephen P \& Coulter, Mary. 2012. Perilaku Organisasi, Edisi Kesebelas. Jakarta:Erlangga

[9]. Robbins dalam Mamik. (2010). "Pengaruh Gaya Kepemimpinan, Motivasi Kerja, dan Komitmen Organisasi Terhadap Kinerja Karyawan”, Jurnal Ekonomi, Tahun XX, No. 1 April 2010.

[10]. Robbins, S. P., \& Judge, T. A. (2014). Organizational Behavior (15 ed.). New Jersey: Pearson Education, Inc.

[11]. Sadarmayanti. (2011). Manajemen Sumber Daya Manusia, Reformasi Birokasi dan Manajemen Pegawai Negeri Sipil (cetakan kelima). Bandung: PT Refika Aditama

[12]. Sinambela, L. P. (2016). Manajemen Sumber Daya Manusia Jakarta: Bumi Aksara.

[13]. Sudarmanto (2015). Kinerja dan Pengembangan kompetensi SDM (Cetakan Ketiga 2015). Yogyakarta: Pustaka Pelajar

[14]. Sugiyono. (2014). Metode Penelitian Kuantitatif, Kualitatif, dan Kombinasi (Mixed Methods). Bandung: Alfabeta.

[15]. Sugiyono, P. D., (2010). Metode penelitian pendidikan. Pendekatan Kuantitatif.

[16]. Sugiono. (2009), Metode Penelitian Bisnis, Alfabeta: Bandung. 
[17]. Sumartono,T.A. (2018). Pengaruh kepemimpinan transformasional, Motivasi kerja dan disiplin kerja terhadap Kinerja guru. Universitas Mercu Buana.

[18]. Sutarto Wijono. 2010. Psikologi Industri dan Organisasi : Dalam Suatu Bidang Gerak Psikologi Sumber Daya Manusia. Jakarta. Kencana Prenada Media Group.

[19]. Vizano, N.A., Setiyani, A., dan Lenny Nawangsari. (2018). The Effect of Organizational Culture \& Job Satisfaction On Turn Over Intention, With Organizational Commitment As a Mediating Variable (Study Case At PT SAS Kreasindo Utama). Jurnal Ekonomi/Volume XXIII,No. 01,Maret 2018: 99-113.

[20]. Wibowo, (2010), Budaya Organisasi, Jakarta: Rajawali Pers.

[21]. Yulk, Gary. 2015. Kepemimpinan dalam organisasi. Indeks: Jakarta.

[22]. LAKIP.2016. Laporan Akuntabilitas Kinerja Instansi Pemerintah (LAKIP) tahun 2016 Badan Pengembangan Sumber Daya Manusia.

[23]. LAKIP. 2017. Laporan Akuntabilitas Kinerja Instansi Pemerintah (LAKIP) tahun 2017 Badan Pengembangan Sumber Daya Manusia.

[24]. LAKIP. 2018. Laporan Akuntabilitas Kinerja Instansi Pemerintah (LAKIP) tahun 2018 Badan Pengembangan Sumber Daya Manusia.

[25]. e-HRM.(2017). Periodik Data Kepegawaian, Badan Pengembangan Sumber Daya Manusia. Diperoleh 23 Oktober 2019, dari https://ehrm.pu.go.id/

[26]. e-HRM.(2018). Periodik Data Kepegawaian, Badan Pengembangan Sumber Daya Manusia. Diperoleh 23 Oktober 2019, dari https://ehrm.pu.go.id/

[27]. e-HRM.(2019). Periodik Data Kepegawaian, Badan Pengembangan Sumber Daya Manusia. Diperoleh 23 Oktober 2019, dari https://ehrm.pu.go.id/ 